\title{
DIE REFORMATORE EN DIE SENDING
}

deu.

\author{
Ds. J. G. DU Plessis
}

Wanneer uit die geskiedenis van die Sending opgemerk word dat, in die eeue onmiddellik na die Kerkhervorming, Sendingverenigings en Sendinggenootskappe, buite die Kerk om, verantwoordelikheid aanvaar het vir die sendingwerk onder die heidense volke in die nuutontdekte lande en wêrelddele, terwyl die Reformatoriese Kerk self blykbaar geen belangstelling openbaar het nie, in elk geval wat die uitstuur van sendelinge na veraf lande betref, kom die vraag na die opvatting van die Reformatore oor hierdie aangeleentheid, onwillekeurig na vore.

Onder diegene wat 'n mening hieroor neergeskryf het, is daar sommige wat meen dat die Reformatore geen oor gehad het vir die sendingopdrag van Jesus Christus aan Sy Kerk nie en wat die Reformatore dan sonder meer daaroor verkwalik. So 'n skrywer is ds. H. A. Wiersinga in sy werk „Geschiedenis van de Zending". ') Ander erken weer 'n leemte in hierdie verband by die Reformatore, maar probeer hulle verskoon deur verskeie redes aan te voer waaroor hulle, dit is die Reformatore, dan hierdie aspek verwaarloos het. Dr. J. H. Bavinck, soos hy in sy werk ,Zending in een wereld in Nood" ") daaroor skryf, is een van hierdie lg. skrywers. 'n Derde groep meen dat die beskuldiging teen die Reformatore nie geregverdig is nie en probeer dan die Reformatoriese sending-opvatting verduidelik en uiteensit. So 'n skrywer is Hans Werner Gensichen in die werk "Missionsgeschichte der neueren Zeit". ${ }^{3}$ )

Dat daar oor hierdie aangeleentheid so 'n meningsverskil bestaan, kom eienaardig voor, maar 'n nadere ondersoek bring aan die lig dat die rede vir hierdie verskil nie soseer by die Reformatore te soek is nie, maar eerder by die skrywers self. Die maatstaf waarmee elke skrywer meet, d.w.s. die afsonderlike opvattinge wat die skrywers self oor die sending het, bring hierdie verskil in beoordeling van die Reformatore op hierdie

1) H. A. Wiersinga, Geschiedenis van de Zending, J. H. Kok N. V. Kampen. 1959. bl. $28-35$.

bl. $108 \cdot 110$.

2) J. H. Bavinck, Zending in een wereld in Nood, Wageningen, 1948,

3) H. W. Gensichen, Missionsgeschichte der neueren Zeit, Ein Handbuch; Die Kirche in ihrer Geschichte, Vandenhoeck en Ruprecht, Göttingen, 1961 , bl. $5-9$. 
gebied van die teologie mee. So is dit duidelik dat wanneer Wiersinga beweer: ,Luther en Calvijn hebben de roeping der Kerk in dezen (Zending) niet duidelijk onderkend", ") hy van 'n heel ander maatstaf gebruik maak as Gensichen wanneer $1 \mathrm{~g}$. dit stel: „Was zunächst Luther (und Calvin) betrifft, so gibt es bei ihm in der Tat keine isolierte Theologie oder Methodik der Heidenmission, und das nicht infolge zeit- und situationbedingter Enge des Horizonts, sondern weil seine gesamte Theologie die missionarische Dimension bercits in sich trägt". ")

Alles in ag geneem is dit seker dat die hele aangeleentheid van verskil van mening oor die Reformatoriese sendingopvatting, te make het met die subjektivisties-metodisties-piëtistiese sendingsbenadering en -opvatting van die einde $18 \mathrm{e}$ en begin $19 \mathrm{e}$ eeu. Diegene wat die Reformatore so kras veroordeel, en selfs sommige van dié wat hulle dan probeer verskoon, beoordeel die Reformatoriese opvatting vanuit die standpunt en benadering van die sendinggenootskappe en -verenigings van die genoemde eeu. Vir hierdie genoemde veroordelendes, by wie dit eintlik maar altyd gaan om die subjektiewe belewing van die Woord, staan of val die sending by die feit dat spesifieke mense afgesonder moet word (sendelinge) en uitgestuur moet word na afgeleë plekke en heidense volke of lande.

So is dit te verstaan dat 'n skrywer soos Wiersinga, hoewel hy self sê dat dit 'n uitgangspunt van die Reformatore was om ,als men door omstandigheden met heidenen of Mohammedanen in aanraking sou komen, deed men goed dezen het Evangelie te laten horen', ${ }^{6}$ ) die Reformatore beskuldig dat hulle niks van die Kerk se taak as Sendingkerk begryp het nie, bloot omdat hulle nie ,er expres op uitgaan met het doel verre volken het Evangelie te brengen". ") Ook uit sy waardering vir die standpunt van Erasmus en Bucer is dit duidelik dat, vir hom, die Kerk dan alleen besig is om die opdrag van Matt. 28:19 uit te voer, wanneer die Kerk spesifiek afgesonderde sendelinge die wêreld instuur. Die belangrike is vir hom die sendelinge wat uitgestuur word en die feit dat die kerk, en dus die lidmate van die kerk, self gestuurde in die wêreld is, het vir hom geen waarde in hierdie verband nie. Met dieselfde $19 \mathrm{e}$ eeuse maatstaf meet hy as hy verder sê: „Dat ook thans nog vele lutherse en gereformeerde (Hervormde) kerken zo weinig een Zendings-

\footnotetext{
f) H. A. Wiersinga, a.w., bI. 29

5) H. W. Gensichen, a.w., bl. 6.

6) H: A. Wiersinga, a.w., bl. 29.

¡) H. A. Wiersinga, a.w., bl. 29.
} 
aangezicht hebben, komt wel hiervandaan", ${ }^{8}$ ) (d.w.s. dit is 'n uitvloeisel van die Reformatoriese opvatting), 'n beskuldiging wat vir die Nederduitsch Hervormde Kerk van Afrika nie nuut is nie.

Dat hierdie sendingvereniging-georiënteerde benadering menige teoloog se opvatting oor hierdie aangeleentheid oorheers, word ook bewys deur die feit dat selfs diegene wat die Reformatore wil verdedig, dit op dieselfde grondslag en teen dieselfde voorwaardes doen as diegene wat die Reformatore veroordeel.

In hierdie verband word daar dan op gewys dat Calvyn predikante uit Geneve na Brasilië gestuur het om daar, in 'n sekere sin, die Evangelie aan die inboorlinge te bring. (Terloops, 'n sending wat misluk het en 'n negatiewe uitwerking op die Geneefse gemeente moes gehad het.) Daar word ook in hierdie verband verwys na die besondere omstandighede waarin die Reformatore verkeer het; daar word verwys na die uitverkiesingsleer; die afgeslotenheid van die Apostoliese wêreldkerstening; die feit dat die sendingwerk aan die staat oorgelaat is; ens., maar, hoewel al hierdie bewerings waar is en van waarde is, word die Reformatorie nie daardeur vrygespreek solank die feite steeds met die weegskaal van die $19 \mathrm{e}$ eeuse benadering geweeg word nie.

Om die Reformatore se standpunt oor die sending reg te beoordeel, moet die Reformatoriese teologie in hierdie verband reg verstaan word en moet oor die wese van die sending, BybelsReformatories besin word. Andersom: Daar moet eers uitgemaak word wat presies bedoel word met sending en dan kan uitgemaak word in hoe 'n mate het die Reformatore (en die Reformatoriese Kerk) sig laat lei deur daardie bepaalde riglyne.

'n Vraag wat eers vooraf bedink moet word is, of daar 'n onderskeid gemaak kan word tussen kersteningswerk in die geval waar die kerk bloot d.m.v. die algemene priesterskap van die gelowige die Evangelie verkondig en kersteningswerk in die geval waar sendelinge uitgestuur word na heidense lande en volke; ' $n$ onderskeid dan in dié sin dat lg. handeling as sendingwerk deurgaan, terwyl eersgenoemde nie as sulks kwalifiseer nie. Dit kom neer op die vraag of die kerk dan net sendingwerk doen wanneer die kerk mense (sendelinge) uitstuur na heidense volke en of al die ander handelinge wat die kerk in hierdie

8) H. A. Wiersinga, a.w., bl. 31 . 
verband op grond van sy apostoliese opdrag doen, dan nie as sendingwerk gekwalifiseer kan word nie. Dit lei na die volgende vraag, wat daarop neerkom dat uitgemaak moet word wat Christus primêr bedoel het toe Hy die opdrag gegee het wat in Matt. 28:19 neergeskryf is. Het Hy primêr bedoel : „Gaan heen en stuur sendelinge uit in die wêreld", of het Hy primêr bedoel : "Gaan heen en wees My kerk in die wêreld". Gehoorsaam die kerk hierdie opdrag eers wanneer hy sendelinge uitstuur, of is die feit dat die kerk Christusverkondigende kerk in die wêreld is, reeds die begin van die vervulling van hierdie gebod? Dit wil my voorkom of hierdie soort onderskeid tussen die werk deur die sendelinge en die werk deur die lidmate van die gemeente nie kan deurgaan nie; die een het met die ander te make en albei gaan om dieselfde saak. Ek wil dit dus stel dat na my mening die kerk nie noodwendig sendelinge moet uitstuur om die opdrag van Jesus Christus te gehoorsaam nie. maar dat die kerk dikwels sendingkerk is sonder uitgestuurde sendelinge deurdat die kerk self die gestuurde in die wêreld is, hoewel dit waar is dat die kerk onder sekere omstandighede sendelinge uitstuur, nie omdat die sendelinge die kerk tot sendingkerk maak nie, maar omdat sendelinge dan onder diè besondere omstandighede ' $n$ hulpmiddel vir die kerk is in die uitvoering van die opdrag van Jesus Christus aan Sy gemeente. Die kerk is dus nooit sendingkerk net op grond van sendelinge wat uitgestuur is nie, maar sendelinge word uitgestuur op grond van die feit dat die kerk gesondene en daarom sendende is in hierdie wêreld. In hierdie verband kan daar gelet word op die kersteningswerk van die kerk in die eerste eeu. Nie net het die apostels uitgegaan om die evangelie te verkondig en gemeentes te stig nie, maar veral ook het die Christene self spontaan die evangelie verkondig oral waar hulle gegaan het. ") Trouens, dit wil my voorkom of die apostels, deur hulle opdrag uit te voer, gemeentes tot stand laat kom het, sodat hierdie gemeentes op hulle beurt weer die taak van die apostels verder kon voer. So bemerk 'n mens dat, hoewel die twaalf dissipels van Jesus Christus tot apostels gemaak is deur die direkte bemoeienis van Jesus Christus in die Heilige Gees, Paulus, na sy bekering, eers deur die kerk "georden" is voordat hy met sy taak kon begin. So is daar ook ander in opdrag van die Here, deur die Kerk afgesonder en uitgestuur! Die kerk as gestuurde, as Christusverkondigende sendeling, as sendingkerk deur die toedoen van die spontane verkondiging deur die lidmate, sonder, onder be-

9) H. A. Wiersinga, a.w., bl. 9. 
sondere omstandighede, sendelinge af en stuur hulle uit ter aanvulling van die kersteningswerk wat elke dag deurgaan d.m.v. die lidmate.

Om nou hierdie hele aangeleentheid saam te vat, wil ek dic volgende stelling maak: Sending is die handeling van God waarin Hy Sy kerk van al die eeue gebruik om Sy evangelie aan die mens, wat deur die sonde van God vervreem is en so buite die kerk is, te verkondig, sodat Hy deur Sy Woord en Gees diẽ wat uitverkies is tot die ewige lewe byeen bring in Sy gemeente met die oog op die wederkoms van Christus. In die praktyk hou dit in dat God Sy gemeentes op verskillende wyses gebruik, maar veral op twee maniere :

(i) Direk, deur middel van die algemene priesteramp van die gelowiges en

(ii) Indirek, deur vanuit die midde van die gemeente enkeles deur die gemeente, onder leiding van die Heilige Geees, te laat afsonder en hulle spesifiek te laat uitstuur.

Vir die kerk is bepalend dat in hierdie verband God nie buite Sy kerk om wil handel nie en dat die kerk deur God vir Sy doel gebruik word wanneer die kerk, in gehoorsaamheid aan die opdrag van Jesus Christus, sy dienswerk in die werreld verrig, deur nl. die Evangelie van Jesus Christus na binne en na buite te verkondig deur middel van die algemene amp en/of die besondere amp en/of d.m.v. afgesonderde en uitgestuurde sendelinge.

Met hierdie definisie as maatstaf sal die Reformatore nie so maklik veroordeel kan word as kerkleiers by wie daar niks van die sendingopdrag van Matt. 28:19 tereg gekom het nie en sal die Reformatoriese Kerk ook nie so maklik afgeskryf word as die kerk sonder "sendingsaangesig" nie. Volgens $H$. W. Gensichen moet dit toegegee word dat daar in die teologie van die Reformatore geen afsonderlike stuk oor die heidenevangelisasie is nie, maar dan moet daar nie sonder meer aangeneem word dat daar niks van die apostoliese opdrag by hulle tereg gekom het nie, want die gesamentlike teologie van die Reformatore bevat in beginsel die sendingbeginsels wat by die kerk van Christus gesoek moet word. Met betrekking tot Luther verduidelik hy dat Luther die gemeente as die gestuurde in die wêreld ken. Luther beklemtoon die algemene priesteramp van die gelowiges sodat sy sendingopvatting gemeente-sentries beskou kan 
word en as in die handeling van God gegrond gesien kan word. Hy wys daarop dat daar by Luther ,für ein besonderes missionarisches Amt freilich kein Raum ist, wohl aber für sorgfältige Berücksichtigung der besonderen Bedingungen, unter denen der Zeugnisauftrag jeweils auszurichten ist". "')

Dit is so dat Luther nie gedink het aan die uitstuur van sendelinge nie, maar dit was nie omdat hy die taak van die kerk t.o.v. die sendingwerk verontagsaam het nie, maar wel omdat die omstandighede sodanig was dat die uitstuur van sendelinge nie oorweeg kon word nie. Daar spreek veel uit die feit dat waar in aanraking gekom is met heidense- of niechristelike volke, evangelisasiewerk gedoen is: Vergelyk hier die werk van die Lutherse Kerk m.b.t. die Laplanders en die bemoeienis met die Slawiese volke, asook die Turke en die Jode. Dieselfde geld vir Calvyn. ${ }^{11}$ ) Sy uitverkiesingsleer, wat as sendingvreemd voorgehou word, is in werklikheid sendingaktiverend en, hoewel dit waar is dat hy Matt. 28:19 op die apostels as sulks betrek, het hy tog nie daarmee die apostolaat van die kerk ontken of daardeur beweer dat daar nie meer sending in die wêreld gedoen moet word nie. ${ }^{12}$ ) 'n Bewys hiervan is dat toe die geleentheid hom voordoen, hy Hervormers uit Geneve na Brasilië gestuur het om daar sendingwerk te gaan doen. So is dit ook 'n feit dat met die volvoering van al die konsekwensies van die Calvinistiese teologie, daar later by die sending as sulks uitgekom is, hoewel nie altyd na die sin van die humanistiesgeïnspireerde sendingopvatting, wat die Christelike sendingwerk wil gebruik om die heidense volke die Westerse kultuur aan te leer nie. Hoe dit ook al sy, feit is dat die Reformatore besig gehou is deur die Contra-reformasie en daarom nie in die geleentheid was om hulle sendingbeginsels, soos dit in hulle teologie vervat was, te ontwikkel en prakties toe te pas nie. Niemand sal egter wil beweer dat die Reformatore en die Reformatoriese Kerk, waarvan die Nederduitsch Hervormde Kerk van Afrika ook 'n deel is, alles gedoen het en alles gesê het wat nodig was om te doen en te sê m.b.t. die sendingwerk van dio kerk in die wêreld nie, maar om te aanvaar dat daar by die Reformatore en die Reformatoriese Kerk, soos die Ned. Herv. Kerk van Afrika, niks van die Christelike sending tereg gekom het nie, is nie regverdig nie. As die Reformatore en die Reformatoriese Kerk van die apostolaat van die kerk niks begryp het

1i) H. W. Gensichen, a.w., bl. 6.

11) H. W. Gensichen, a.w., bl. 7 .

12) Vgl. bv. die formuliere van enigheid van die Calvinistiese Kerk. 
nie, sou hulle begrip van kerk en die taak van die kerk in die wêreld, geheel anders daar uitgesien het.

Daar moet daarteen gewaak word dat by die besinning oor ' $n$ aangeleentheid soos hierdie en by die besinning oor die werk van die kerk in hierdie verband, ' $n$ mens nie op sleeptou geneem en gelei word deur die piëtisties-metodistiese sendingopvatting van die $18 \mathrm{e}$ en $19 \mathrm{e}$ eeu wat die sendinggenootskappe en sendingverenigings tot gevolg gehad het nie. So 'n dwaling kan tot gevolg hê dat die werk van die kerk in hierdie verband baie skade berokken word, soos dit uit die geskiedenis met sekerheid te bewys is dat dit juis die houding en benadering van die London Sendinggenootskap was wat veroorsaak het dat die Ned. Herv. Kerk van Afrika nie ten volle hierdie werk kon verrig nie, omdat die kerk eers lank moes worstel om van die stigma, wat deur hierdie sendingvereniging aan die sendingwerk gegee is, ontslae te raak.

Ten slotte wil ek dit dan stel dat, al wil dit teen die agtergrond van die sendinggenootskappe, sendinginstitute en sendingverenigings voorkom dat die Reformatore en die Reformatoriese Kerk niks in verband met die sending gedoen het nie, dit in werklikheid nie so is nie, omdat sendingwerk saamval met kerkwees, en as die kerk kerk sou wees in die wêreld soos die Reformatore o.g.v. die Bybel dit voorgeskryf het, dan sou die Kerk niks anders as gesondene, en daarom as sendende kerk, in die wêreld kon wees nie. 